\title{
Phylogenetic Analysis and Extracellular Enzyme Profiles of Yeast Strains Isolated from Raspberry Fruits
}

\author{
Tülay Turgut Genç ${ }^{1 *}$, Melih Günay ${ }^{2}$ \\ ${ }^{1}$ Department of Biology, Faculty of Arts and Science, Biology, Çanakkale Onsekiz Mart University, Çanakkale, Turkey \\ ${ }^{2}$ Department of Biology, Graduate School of Natural and Applied Sciences, Çanakkale Onsekiz Mart University, Çanakkale, Turkey
}

\begin{abstract}
Article History
Received: $\quad 30.01 .2020$

Accepted: $\quad 30.12 .2020$

Published: $\quad 20.03 .2021$
\end{abstract}

Research Article

\begin{abstract}
Raspberry fruit contains phenolic compounds, flavones, flavonoids, vitamins, and antioxidant substances that are important properties for health and pharmacological sciences. Edible berries provide also a suitable habitat for the growth of various microorganisms. In this study, yeast biota associated with raspberry fruits was determined by molecular identification techniques. Raspberry fruits were collected from Çanakkale, Gelibolu (Gallipoli). Yeast strains were isolated and then identified by using the analysis of ITS1-5.8S-ITS2 rDNA gene sequences. The phylogenetic analysis of all yeast strains was carried out by using the MEGA-X phylogenetic analysis tool. The extracellular enzyme profiles of identified yeast species were determined by the API-ZYM kit system. The distribution of yeast species on the raspberry fruits was determined as Hanseniaspora uvarum, Metschnikowia viticola, Aureobasidium pullulans, and Metschnikowia pulcherrima. It was observed that yeast strains belong to Metschnikowia genus were dominant on raspberry fruits. All yeast strains in Metschnikowia genus showed different enzyme profiles against seven extracellular enzymes. These enzymes may be the discriminatory enzymes for the yeast strains in the Metschnikowia genus. When the phylogenetic relationships among all yeast strains were investigated, all strains were divided into two main clades. While the first clade consists of only Metschnikowia genus, second clade includes $H$. uvarum and A. pullulans yeast species. Our results indicated that restriction patterns and also extracellular enzyme profiles could be utilized for differentiation of yeast strains within the genus. M. pulcherrima, H. uvarum, and A. pullulans can be used for industrial applications for future researches.
\end{abstract}

Keywords - Extracellular enzymes, PCR-RFLP, Raspberry, Yeast biota

\section{Introduction}

Raspberry fruit (Rubus idaeus L.) belongs to Rosacea family, naturally distributed in Canada, the USA, and Europe (Wang, Laamanen, Uosukainen, \& Valkonen, 2005). Raspberry plants can grow about $1000 \mathrm{~m}$ altitude and humid regions throughout in northern line of Turkey (Göktaş, 2011). Raspberry fruits contain a great amount of valuable nutrients such as (poly)phenolic compounds, flavones, flavonoids, and vitamins. The phytochemicals and antioxidants contents of raspberry berries are important for diminishing biological oxidative stress in mammalian cells (Kähkönen et al., 1999; Halvorsen et al., 2001; Weber and Liu, 2002). Glycosylated phenol salidroside, one of the bioactive compounds of raspberry fruits, has therapeutic potential as it shows activity against the pathological processes of Huntington's disease (HD) (Kallscheuer et al., 2019). HD is a neurodegenerative disorder caused by the loss of striatal neurons due to the aggregation of huntingtin proteins encoded by the HTT gene (The Huntington's Disease Collaborative Research Group, 1993). Many studies were conducted antimicrobial potential of different parts of raspberry fruits (Puupponen-Pimia et al., 2005; Krisch, Galgóczy, Papp, \& Vagvolgi, 2009; Riaz, Ahmad, \& Rahman, 2011;

\footnotetext{
(iD) tturgutgenc@comu.edu.tr

2 (iD)

*Corresponding Author
} 
Velićanski, Cvetković, \& Markov, 2012). In addition, raspberry fruits are used for wine production, due to having different acids and anthocyanin pigment as well as fructose (Duarte et al., 2010).

Microbial enzymes are utilized in many fields such as biofuel production, animal feeds and, the medical industry. In the food industry, these enzymes are used in mainly dairy products, wine production, and bakery. Microbial enzymes are effective in enhancing the flavor and nutrient values of the products during the fermentation process (Wang, Li, Yang, Yang, \& Zhu, 2012). Yeasts are a significant microorganism for determining food microbial quality and producing fermented products. Most of the microbial enzymes were obtained from different yeast species such as Saccharomyces cerevisiae, Kluyveromyces lactis, Geotrichum candidum, Yarrowia lipolytica, Rhodotorula spp., Kluyveromyces marxianus, Komagataella pastoris, Debaryomyces hansenii, Cryptococcus spp., Cryptococcus laurentii, Sporobolomyces salmonicolor (Johnson, 2013a, 2013b).

Microbial diversity on raspberry fruits was limited on molds and bacteria in different researches (Tournas \& Katsoudas, 2005; Leff \& Fierer, 2013). The yeasts associated with raspberry fruits have not been identified and characterized with molecular techniques yet. Therefore, in this research yeast strains were isolated from raspberry fruits collected from Gallipoli, Çanakkale-Province, and identified by using analysis of PCR-RFLP and ITS1-5.8S-ITS2 gene sequences. The phylogenetic analysis of all yeast strains was carried out by using the MEGA-X phylogenetic analysis tool. The extracellular enzyme profiles of yeast strains were determined with the API-ZYM kit system. Hanseniaspora uvarum, Aureobasidium pullulans, Metschnikowia viticola and Metschnikowia pulcherrima were identified on raspberry fruits. Metschnikowia genus was dominated more than half of yeast microbiota on raspberry fruit. All identified $H$. uvarum and A. pullulans yeast strains and nine of the isolated $M$. pulcherrima yeast strains were displayed a high level industrially important $\beta$ glucosidase activity.

\section{Materials and Methods}

\subsection{Yeast Strains}

Raspberry fruits were collected aseptically from Gelibolu-Turkey (40 $51^{\prime} 50^{\prime \prime}$ North Latitude, $26^{\circ} 37^{\prime} 20^{\prime \prime}$ East longitude) taking into account of ripening period. Raspberry fruits were weighed and homogenized in $2 \%$ sodium citrate solution, were spread onto YGC-Agar medium (40 gr/l Yeast Extract Glucose Chloramphenicol Agar) including 0.1\% sodium propionate. Plates were incubated at $30{ }^{\circ} \mathrm{C}$ for $2-3$ days, the growing yeast colonies were counted to determine the colony forming units (CFU/gr). Yeast strains, having different colony morphology, were selected randomly and transferred to YEPD medium (10 gr/l Yeast Extract, $20 \mathrm{gr} / \mathrm{l} \mathrm{Bacto-peptone,} 20 \mathrm{gr} / \mathrm{l} \mathrm{Agar,} 2 \%$ Dextrose). After incubation of plates at $30{ }^{\circ} \mathrm{C}$ for $2-3$ days, the isolated yeast strains were stored at $-80^{\circ} \mathrm{C}$ for further use.

\subsection{PCR-RFLP Analysis}

Genomic DNA extraction of yeast strains was carried out by a previously developed DNA extraction procedure (Sherman, Fink, \& Hicks, 1986). ITS1-5.8S-ITS2 rDNA gene regions of all strains were amplified by using universal primers, ITS1 (5'-TCCGTAGGTGAACCTGCGG-3') and ITS4 (5'TCCTCCGCTTATTGATATGC-3'), for yeast strains and amplification was studied by previously reported conditions (White et al., 1990). PCR products were electrophoresed and the length of PCR amplicons was calculated by Gel-Pro Analyzer v4.0 software. PCR products of ITS1-5.8S-ITS2 rDNA gene regions were purified GeneJet PCR Purification Kit (Thermo Scientific - K0702) and were digested with Hae III, Hinf I, Msp I, Hha I, and Alu I restriction endonucleases, according to supplier's instructions. The length of restriction fragments was calculated by using Gel-Pro Analyzer v4.0 software The yeast strains were classified with respect to restriction patterns. 


\subsection{Sequencing and Phylogenetic Analysis}

PCR products of all yeast strains were sequenced by utilizing the Applied Biotechnologies 3500xl Genetic Analyzer. The attained ITS1-5.8S-ITS2 rDNA gene sequences were analyzed using the BLAST (Basic Local Alignment Search Tool) online tool on NCBI (National Center for Biotechnology Information) webserver. All sequences of ITS1-5.8S-ITS2 region were uploaded to GenBank with the accession numbers MN556577-MN556603. ITS1-5.8S-ITS2 rDNA sequences of all yeast strains were studied by using MEGA-X (Molecular Evolutionary Genetics Analysis) software (Kumar et al., 2018). The nucleotide sequences of the ITS1-5.8S-ITS2 gene region of all yeast strains and two outgroups (Saccharomyces cerevisiae and Pichia guilliermondii) were aligned with ClustalW (v1.6) algorithm in MEGA-X. Maximum parsimony tree was constructed by using a bootstrap method and Subtree-Pruning-Regrafting (SPR) parameters for the determination of phylogenetic relationships of yeast strains. 1000 bootstrap replicates were used to defined branch support and bootstrap values above $50 \%$ were given.

\subsection{Extracellular Enzyme Profiles}

Extracellular enzyme profiles of identified yeast strains were determined by using the API-ZYM kit system (Bio-Mérieux, France). API-ZYM kit system is a minimized and semi-quantitative test system and utilized for screening 19 different enzyme activities (Alkaline phosphatase, Esterase (C 4), Esterase Lipase (C 8), Lipase (C 14), Leucine arylamidase, Valine arylamidase, Cysteine arylamidase, Trypsin, $\alpha$ chymotrypsin, Acid phosphatase, Naphthol-AS-BI-phosphohydrolase, $\alpha$-galactosidase, $\beta$-galactosidase, $\beta$ glucuronidase, $\alpha$-glucosidase, $\beta$-glucosidase, $\mathrm{N}$-acetyl- $\beta$-glucosaminidase, $\alpha$-mannosidase, $\alpha$-fucosidase). All yeast strains were grown in YEPD medium at $30^{\circ} \mathrm{C}$ for 12 hours with constant shaking $(120 \mathrm{rpm} / \mathrm{rev})$. The $65 \mu \mathrm{L}$ from the saturated yeast culture were transferred to each microwells of the API-ZYM strip. The APIZYM strips were incubated at $37^{\circ} \mathrm{C}$ for 4 hours. After that, ZYM A and ZYM B reagents were added to each cupule and all the strips were incubated at room temperature for 5 minutes. Enzyme profiles of yeast strains were defined by a color scalar of API-ZYM kit system (0-5 scalar).

\section{Results and Discussion}

\subsection{Identification of Yeast Strains}

In our study, the diversity of yeasts species on raspberry fruits has been investigated and the total yeast counts were calculated as $1.2 \mathrm{X} 10^{3} \mathrm{CFU} / \mathrm{gr}$. Depending on the colony morphology differences twenty-seven yeast strains were selected randomly for further identifications. Yeast strains were classified into five groups according to their colony morphology features such as colony color, colony margin, colony top, etc. (Table 1). The amplification of ITS1-5.8S-ITS2 rDNA gene region of yeast strains resulted in three PCR groups with the length of $\sim 400 \mathrm{bp}$ (18 yeast strains) $\sim 650 \mathrm{bp}$ (2 yeast strains) and $\sim 800 \mathrm{bp}$ (7 yeast strains) (Table 2). When the yeast strains present in PCR groups and the colony morphology groups were compared, the yeast strains (R-3, R-6, R-23, and R-25) having different colony morphologies localized within the same PCR group. 
Table 1

Grouping of yeast strains according to colony morphologies.

\begin{tabular}{ll}
\hline Group No & Yeast Strains \\
\hline 1 & R-1, R-2, R-4, R-5, R-7, R-8, R-9, R-10, R-12a, R-13, R-14, R-15, R-24, R-26 \\
2 & R-3, R-25 \\
3 & R-6 \\
4 & R-11, R-12b, R-16, R-17, R-18, R-19, R-20, R-22, R-23 \\
5 & R-21 \\
\hline
\end{tabular}

The analysis of the restriction profile of ITS1-5.8S-ITS2 gene region has been used to identify yeast strains isolated from natural sources and to determine strains discrepancy (Carvalho, Meirinho, Estevinho, \& Choupina, 2010). Therefore, all yeast strains were cleaved with five restriction enzymes (Hinf I, Hae III, Msp I, Alu I, and Hha I) and were grouped again for the PCR-RFLP analysis (Table 2). The yeast strains in the first PCR group displayed two different restriction profiles. The PCR products of all yeast strains in the first group were not digested with Alu I, and three yeast strains (R-3, R-6, and R-25) were not digested with Msp I restriction enzyme. The yeast strains present in the second PCR groups showed similar restriction patterns with the group members. By means of PCR-RFLP analysis, four different restriction profiles were attained. We assumed that each restriction profile may represent to different yeast strains.

As indicated in previous reports, the colony morphology and/or PCR size alone is not sufficient for distinguishing yeast strains and, the RFLP analysis was essential for discrimination of yeast strains. The PCR-RFLP results of ITS1-5.8S-ITS2 gene region are similar to previous studies which are especially used Hae III, Hinf I and Hha I (Cfo I) restriction endonucleases (Guillamon, Sabate, Barrio, Cano, \& Querol, 1998; Rodriguez-Vico, Clemente-Jimenez, Mingorance-Cazorla, Martinez-Rodriguez, \& Las HerasVazquez, 2003; Romano, Capece, Siesto, \& Romaniello, 2009; Gibson et al., 2011). The Hae III, Hinf I, and Hha I restriction pattern of second group members was similar to $M$. pulcherrima yeast species recorded in previous studies (Esteve-Zarzoso, Belloch, Uruburu, \& Querol, 1999; Rodriguez-Vico et al., 2003).

Table 2

PCR-RFLP results of yeast strains

\begin{tabular}{|c|c|c|c|c|c|c|c|}
\hline \multirow{2}{*}{$\begin{array}{l}\text { PCR Length } \\
(\sim \mathrm{bp})\end{array}$} & \multirow{2}{*}{$\begin{array}{l}\text { Restriction } \\
\text { Profiles }\end{array}$} & \multirow{2}{*}{ Yeast Strains } & \multicolumn{5}{|c|}{ Restriction Product Length $(\sim \mathrm{bp})$} \\
\hline & & & Hae III & Hinf I & Msp I & Alu I & Hha I \\
\hline & 1 & R-3, R-6, R-25 & $289-120$ & $215-186$ & - & - & $217-99-90$ \\
\hline$\sim 400$ & 2 & $\begin{array}{l}\text { R-1, R-2, R-4, R-5, R-7, } \\
\text { R-8, R-9, R-10, R-12a, } \\
\text { R-13, R-14, R-15, R-23, } \\
\text { R-24, R-26 }\end{array}$ & 286-109 & $192-188$ & $224-120-60$ & - & $208-96-90$ \\
\hline$\sim 650$ & 3 & R-20, R-22 & $441-150$ & $278-168-129$ & 270-184-141 & $387-207$ & $183-179-108-94$ \\
\hline$\sim 800$ & 4 & $\begin{array}{l}\mathrm{R}-11, \mathrm{R}-12 / \mathrm{b}, \mathrm{R}-16, \\
\mathrm{R}-17, \mathrm{R}-18, \mathrm{R}-19, \mathrm{R}- \\
21\end{array}$ & 750 & $353-184-164$ & 743 & $353-184-164$ & $331-324$ \\
\hline
\end{tabular}

In this research, the ITS1-5.8S-ITS2 rDNA gene region of all yeast strains was sequenced. The obtained sequences were analyzed by the BLAST tool on the NCBI web server. The nucleotide sequences of the ITS1-5.8S-ITS2 rDNA gene region were submitted to the GenBank Database on NCBI and attained acces- 
sion number for all sequences (Accession Number: MN556577-MN55603) (Table 3). According to the BLAST analysis of ITS1-5.8S-ITS2 rDNA gene region, all yeast strains displayed 95-100\% similarity with their reference yeast strains except the R-4 yeast strain. It was determined that all yeast strains in the first PCR group ( 400 bp) were the member of Metschnikowia genus. Three yeast strains (R-3, R-6, and R-25) showed 98-99\% sequence similarity with $M$. viticola reference yeast strain (KY104213.1). M. viticola was firstly isolated from wild grapes (Peter, Tornai-Lehoczki, Suzuki, \& Dlauchy, 2005). In our research, $M$. viticola yeast species was recorded first time on raspberry fruits. Also, RFLP profile of M. viticola was displayed for the first time in our research. Restriction digestion with Msp I can be used for distinguishing the M. viticola species from $M$. pulcherrima yeast species.

All other yeast strains in the first PCR group showed nearly 95\% similarity with $M$. pulcherrima reference yeast strain (NR_164379.1) except R-4 (91\% similarity). The taxonomic identification of M. pulcherrima yeast strains by comparing their rDNA sequences with those deposited in databases can easily lead to false results. Because of the sequences of $M$. pulcherrima yeast strains were deposited in the database without an expert taxonomic verification. Because of the non-homogenized rDNA repeats and the frequent heterozygosity of barcode genes, the type strains of the species of the $M$. pulcherrima clade are not separated by clear barcode gaps (reviewed in Sipiczki, 2020). The colony morphologies, pigment secretion pattern, and RFLP profile of all identified $M$. pulcherrima yeast species were similar in our research. However, the yeast species defined as M. pulcherrima should be analyzed taxonomically, as indicated in Sipiczki's review.

Table 3

Blast analysis of ITS1-5.8S-ITS2 rDNA gene region.

\begin{tabular}{|c|c|c|c|}
\hline Yeast Strains & $\begin{array}{l}\text { Similarity } \\
(\%)\end{array}$ & $\begin{array}{l}\text { Identified Yeast Strains } \\
\text { (Ref. Acc. Number) }\end{array}$ & $\begin{array}{l}\text { GenBank } \\
\text { Accession Number }\end{array}$ \\
\hline R-1 & $97.92 \%$ & M. pulcherrima (NR_164379.1) & MN556577 \\
\hline $\mathrm{R}-2$ & $97.33 \%$ & M. pulcherrima (NR_164379.1) & MN556578 \\
\hline $\mathrm{R}-3$ & $98.75 \%$ & M. viticola (NR_077083.1) & MN556579 \\
\hline $\mathrm{R}-4$ & $91.20 \%$ & M. pulcherrima (NR_164379.1) & MN556580 \\
\hline $\mathrm{R}-5$ & $97.80 \%$ & M. pulcherrima (NR_164379.1) & MN556581 \\
\hline R-6 & $97.11 \%$ & M. viticola (KY104213.1) & MN556582 \\
\hline $\mathrm{R}-7$ & $97.31 \%$ & M. pulcherrima (NR_164379.1) & MN556583 \\
\hline $\mathrm{R}-8$ & $97.04 \%$ & M. pulcherrima (NR_164379.1) & MN556584 \\
\hline R-9 & $95.54 \%$ & M. pulcherrima (NR_164379.1) & MN556585 \\
\hline $\mathrm{R}-10$ & $95.25 \%$ & M. pulcherrima (NR_164379.1) & MN556586 \\
\hline $\mathrm{R}-11$ & $99.02 \%$ & H. uvarum (KY103569.1) & MN556587 \\
\hline $\mathrm{R}-12 \mathrm{a}$ & $96.47 \%$ & M. pulcherrima (NR_164379.1) & MN556588 \\
\hline $\mathrm{R}-12 \mathrm{~b}$ & $98.88 \%$ & H. uvarum (KY103569.1) & MN556589 \\
\hline $\mathrm{R}-13$ & $97.33 \%$ & M. pulcherrima (NR_164379.1) & MN556590 \\
\hline R-14 & $96.75 \%$ & M. pulcherrima (NR_164379.1) & MN556591 \\
\hline $\mathrm{R}-15$ & $96.75 \%$ & M. pulcherrima (NR_164379.1) & MN556592 \\
\hline $\mathrm{R}-16$ & $100.00 \%$ & H. uvarum (KY1035671.1) & MN556593 \\
\hline $\mathrm{R}-17$ & $99.25 \%$ & H. uvarum (KY1035671.1) & MN556594 \\
\hline $\mathrm{R}-18$ & $100.00 \%$ & H. uvarum (KY1035671.1) & MN556595 \\
\hline R-19 & $100.00 \%$ & H. uvarum (KY1035671.1) & MN556596 \\
\hline $\mathrm{R}-20$ & $99.42 \%$ & A. pullulans (MG890282.1) & MN556597 \\
\hline R-21 & $95.68 \%$ & H. uvarum (KY103569.1) & MN556598 \\
\hline $\mathrm{R}-22$ & $98.90 \%$ & A. pullulans (KY552634.1) & MN556599 \\
\hline $\mathrm{R}-23$ & $96.44 \%$ & M. pulcherrima (JN229413.1) & MN556600 \\
\hline
\end{tabular}




\begin{tabular}{llll} 
R-24 & $96.78 \%$ & M. pulcherrima $($ NR_164379.1) & MN556601 \\
R-25 & $98.56 \%$ & M. viticola $($ NR_077083.1) & MN556602 \\
R-26 & $94.97 \%$ & M. pulcherrima (NR_164379.1) & MN556603 \\
\hline
\end{tabular}

R-20 and R-22 yeast strains present in the second PCR group showed 98-99\% sequence similarity with $A$. pullulans yeast species. There is no reference type strain for A. pullulans in the GenBank Database on NCBI. Therefore, the highest percent sequence similarity results were given in Table 3 for A. pullulans yeast species. Seven yeast strains $(\mathrm{R}-11, \mathrm{R}-12 \mathrm{~b}, \mathrm{R}-16, \mathrm{R}-17, \mathrm{R}-18, \mathrm{R}-19$, and $\mathrm{R}-21)$ in the third PCR group displayed 96-99\% sequence similarity with $H$. uvarum reference yeast species (KY103569.1). These results revealed that the restriction endonucleases utilized for RFLP analysis were suitable for the discrimination of yeast strains from each other. The percent distribution of yeast species on the raspberry fruits was determined as $55.6 \% \mathrm{M}$. pulcherrima, $25.9 \% \mathrm{H}$. uvarum, $11.1 \% \mathrm{M}$. viticola, and $7.4 \%$ A. pullulans (Figure 1). It is observed that yeast strains belong to the Metschnikowia genus were dominant on raspberry fruits collected from Gelibolu.

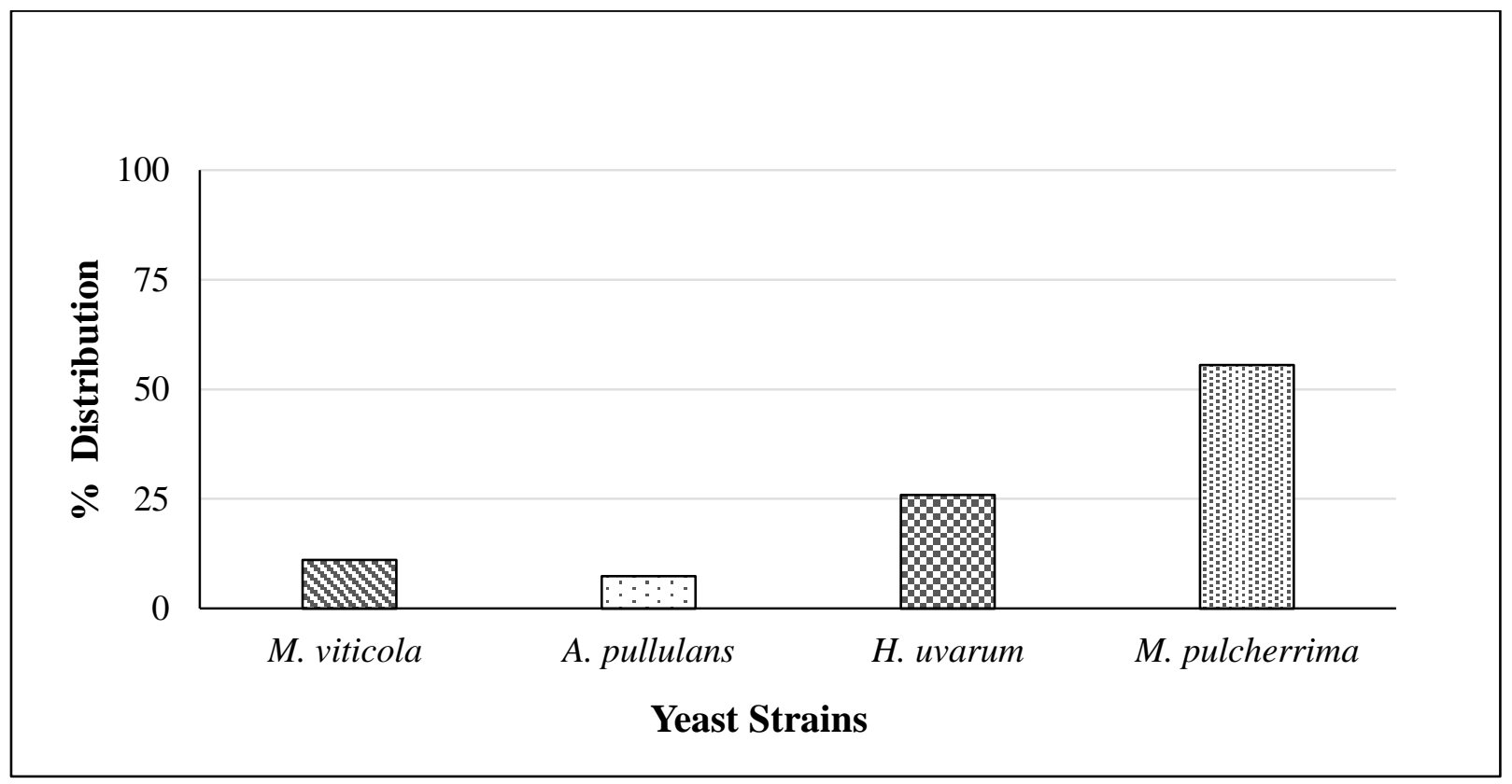

Figure 1. The percent distribution of yeast species on raspberry fruits.

The phylogenetic analysis of all yeast strains was carried out by using the MEGA-X phylogenetic analysis tool. ITS1-5.8S-ITS2 rDNA gene sequences of yeast strains were aligned by the ClustalX v1.6 algorithm and the Maximum parsimony tree was constructed by using default parameters. 1000 bootstrap replicates were used to defined branch support. The percentage of trees is shown next to the branch and frequencies under $50 \%$ are not given. S. cerevisiae and P. guilliermondii yeast species were selected as outgroup. According to the maximum parsimony tree, 27 yeast strains were separated into two main clades. It was determined that the first clade consisted of Metschnikowia genus (M. pulcherrima and M. viticola), the second clade contained H. uvarum and A. pullulans yeast species (Figure 2). As shown in the MP tree, all M. pulcherrima yeast species localized in the first sub-clade. The second sub-clade includes $M$. viticola yeast species that were also discriminated as a different group with RFLP results. The second main clade is divided into two sub-clades. All H. uvarum and A. pullulans yeast species localized in the third and fourth sub-clades, respectively. These yeast strains also showed two different restriction patterns in the RFLP results. All these results indicated that, RFLP results and MP analysis consistent with each other. 
The non-Saccharomyces yeast strains are frequently utilized for biotechnological research along with their industrially importance. Yeast strains are generally used for various research, such as biomedical studies, biocontrol agents, bioremediation and fermentation process (Johnson \& Echavarri-Erasun, 2011). M. pulcherrima, H. uvarum, and A. pullulans are good antagonists for post-harvest diseases in many fruits. It was reported that these yeast strains have protective features for Botrytis cinerea-based diseases (Spadaro, Vola, Piano, \& Gullino, 2002; Vero, Garmendia, Gonzalez, Garat, \& Wisniewski, 2010; Liu et al., 2010). A. pullulans yeast species are used as an indicator for environmental pollutions. The pullulan polysaccharide, produced by A. pullulans, have been utilized for different applications, such as the production of commercial capsules for applying diet of diabetic patients (Deshpande, Rale, \& Lynch, 1992; Sena, Costelli, Gibson, \& Coughlin, 2006; Cheng, Demirci, \& Catchmark, 2011). Therefore, the identified yeast species, M. pulcherrima, $H$. uvarum and A. pullulans could be used for various commercial applications in the future.

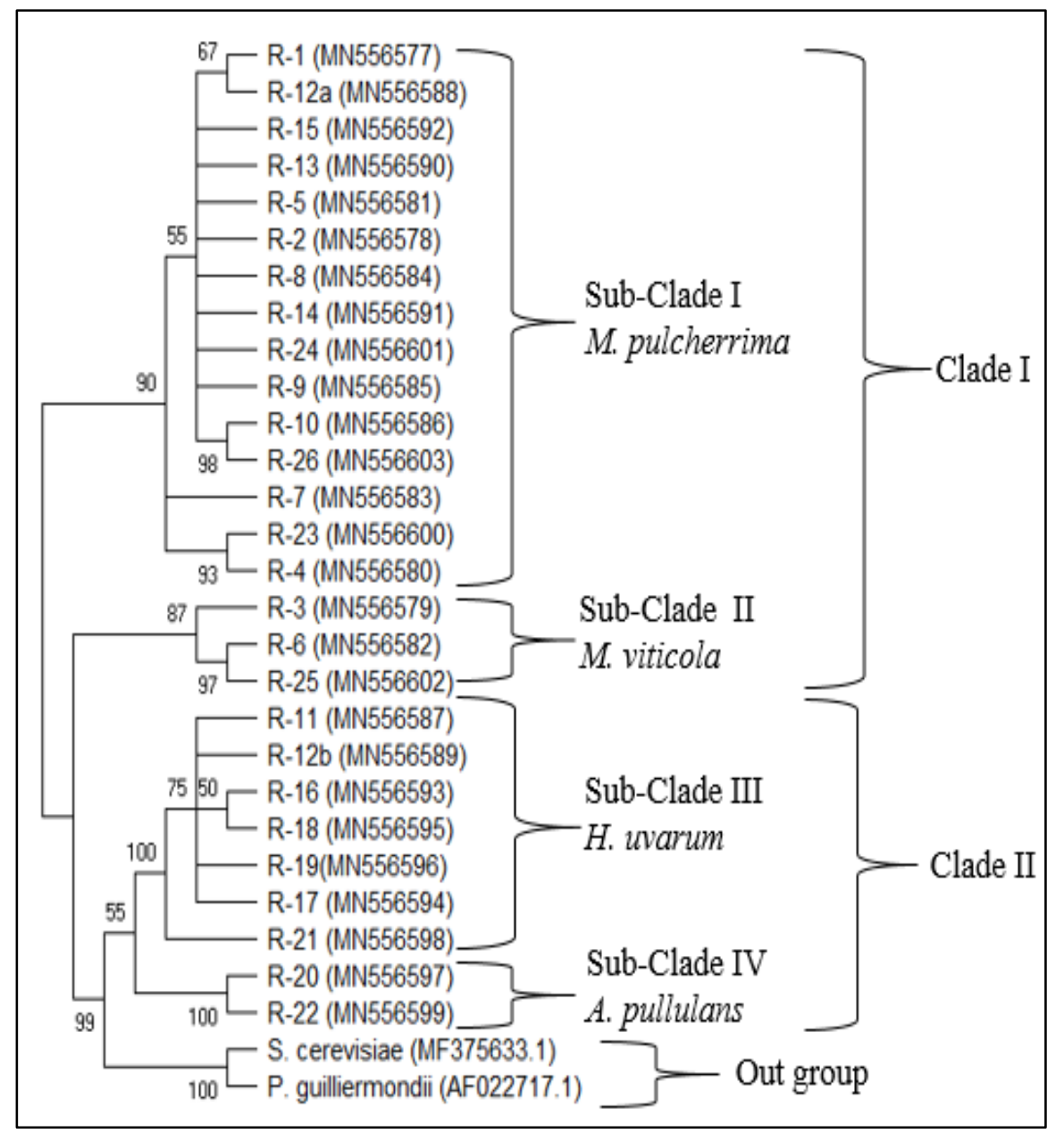

Figure 2. Maximum parsimony tree of yeast strains isolated from raspberry. Maximum parsimony tree of yeast strains isolated from raspberry. MP tree was constructed by using the bootstrap method and SubtreePrunning-Regrafting (SPR) parameters in the MEGA-X software. 1000 bootstrap replicates were used to define branch support and above 50\% bootstrap values were given. S. cerevisiae and P. guilliermondii yeast strains were selected as outgroup.

\subsection{Extracellular Enzyme Profiles}

The extracellular enzymes produced by yeast strains were used to obtain various fermented products. Therefore, the extracellular enzyme activities of all identified yeast strains were investigated. The extracellular enzyme profile of yeast strains was analyzed by using the API-ZYM kit system and the results were given in Table 4 . The lipase (C-14), trypsin, $\alpha$-chymotrypsin, $\alpha$-galactosidase, $\beta$-galactosidase, $\beta$ - 
glucuronidase, $\mathrm{N}$-acetyl-glucosaminidase, $\alpha$-mannosidase, and $\alpha$-fucosidase activities were not recorded in all yeast strains, so, these results were not given in Table 4. All yeast strains showed high leucine arylamidase activity.

It was shown that $M$. viticola, $H$. uvarum and A. pullulans yeast strains have high leucine arylamidase and $\beta$ glucosidase enzyme activity. Interestingly, $M$. pulcherrima yeast strains showed two different extracellular enzyme profiles. In the first profile, six M. pulcherrima yeast strains (R-1, R-4, R-5, R-7, R-12a, R-26) exhibit moderate levels of enzyme activities given in the table. In the second enzyme profile, M. pulcherrima yeast strains (R-2, R-8, R-9, R-10, R-13, R-14, R-15, R-23, R-24) showed a low level of esterase, esterase lipase, acid phosphatase, and naphthol-AS-BI-phosphohydrolase activity and, high level of $\beta$-glucosidase activity. No activity was recorded for the alkaline phosphatase, valine arylamidase, cystine arylamidase, and $\alpha$-glucosidase enzymes. The extracellular enzyme profiles are utilized to define and discriminate yeast strains (Garcia-Martos et al., 2001). In our results, M. pulcherrima yeast strains have different enzyme activities even if they were identified as the same species.

Table 4

Extracellular enzyme profile of yeast strains determined with API ZYM test

\begin{tabular}{|c|c|c|c|c|c|c|c|c|c|c|c|}
\hline Yeast Strains & $\mathrm{C}$ & 1 & 2 & 3 & 4 & 5 & 6 & 7 & 8 & 9 & 10 \\
\hline $\begin{array}{l}\text { M. pulcherrima } \\
\text { (R-2, R-8, R-9, R-10, R-13, R-14, R-15, R- } \\
\text { 23, R-24) }\end{array}$ & 0 & 0 & 1 & 1 & 4 & 0 & 0 & 1 & 1 & 0 & 5 \\
\hline $\begin{array}{l}\text { M. viticola } \\
(\mathrm{R}-3, \mathrm{R}-6, \mathrm{R}-25)\end{array}$ & 0 & 0 & 1 & 1 & 4 & 0 & 0 & 2 & 1 & 1 & 4 \\
\hline $\begin{array}{l}\text { H. uvarum } \\
\text { ( } \mathrm{R}-11, \mathrm{R}-12 / \mathrm{b}, \mathrm{R}-16, \mathrm{R}-17, \mathrm{R}-18, \mathrm{R}-19 \\
\text { ve } \mathrm{R}-21 \text { ) }\end{array}$ & 0 & 0 & 1 & 1 & 4 & 1 & 0 & 1 & 0 & 0 & 5 \\
\hline $\begin{array}{l}\text { A. pullulans } \\
\text { (R-20, R-22) }\end{array}$ & 0 & 0 & 1 & 0 & 4 & 0 & 0 & 0 & 0 & 0 & 4 \\
\hline
\end{tabular}

C, Control; 1: Alkaline Phosphatase; 2: Esterase (C4); 3: Esterase Lipase (C8); 4: Leucine arylamidase; 5 : Valine arylamidase; 6: Cystine arylamidase; 7: Acid Phosphatase; 8: Naphthol-AS-BI-phosphohydrolase; 9: $\alpha$-glucosidase; 10: $\beta$-glucosidase. Results were expressed on a scale from no activity (0) to maximum activity (5).

A. pullulans, $H$. uvarum and some of $M$. pulcherrima yeast strains have $\beta$-glucosidase activity. $\beta$-glucosidase (EC 3.2.1.21) breaks the $\beta-1-4$ glycosidic bond in oligosaccharides. The $\beta$-glucosidase enzyme produced by microorganisms contributes to increasing flavor, aroma, and quality of the wine (Esen, 2003). Another enzyme, leucine arylamidase, is used to increase wine quality of aroma and taste (Dodor \& Tabatabai, 2007; Delfini \& Formica, 2001; Nikolaou, Andrighetto, Lombardi, \& Nikolaos, 2007; Nikolaou, Soufleros, Boulompasi, \& Tzanetakis, 2006; Fleet, Charoenchai, Henschke, \& Todd, 1997). The leucine arylamidase (EC 3.4.11.2), belongs to the aminopeptidase enzyme family, hydrolyzes $\mathrm{N}$-terminal ends of amino acids and, all isolated yeast strains have high leucine arylamidase activity in our research.

\section{Conclusion}

Yeast strains have generally used for biotechnological surveys, such as pharmacology, medicine, drug, enzyme, and food industry. Therefore, the isolation and identification of yeast species from natural habitats are more significant for manufacturers. In this study, the isolated and identified M. pulcherrima, A. pullulans, and $H$. uvarum yeast strains are good candidates for different industrial applications. M. pulcherrima yeast 
species can be used as biocontrol agents to pathogenic microorganisms because of their strong antimicrobial activity. Many antagonistic strains of Metschnikowia have been patented and also some Metschnikowiabased commercial products were used as fermentation additives and biocontrol agents against plant pathogens and post-harvest diseases (reviewed in Sipiczki, 2020). Similarly, A. pullulans yeast species known as black yeast were commercially used for the production of different enzymes (amylase, xylanase, pectinase, etc), and pullulan is the important polysaccharide for the production of biodegradable plastics (reviewed in Gaur et al., 2015). The apiculate yeast species H. uvarum (anamorph Kloeckera apiculata) are also commercialized as oenological starter cultures for the production of volatile compounds in wine (Masneuf-Pomarede et al., 2016). The identified yeast species in our research, M. pulcherrima, H. uvarum, and A. pullulans could be used for different commercial purposes in the future.

\section{Acknowledgement}

This work was supported by the Office of Scientific Research Projects Coordination at Çanakkale Onsekiz Mart University. Grant number: FYL-2014-110.

\section{Author Contributions}

Tülay Turgut Genç: Conceived and designed the analysis, edited the data, wrote and finalized the paper.

Melih Günay: Performed the experimental studies and obtained the data, wrote the paper.

\section{Conflicts of Interest}

The authors declare no conflict of interest.

\section{References}

Abbas, A. C. (2006). Production of antioxidants, aromas, colors, flavors, and vitamins by yeasts. In A. Quarel \& G. Fleet (Eds.), Yeasts in Food and Beverages, vol 2, (pp. 285-334). Springer, Verlag Berlin Heidelberg.

Altschul, S. F., Gish, W., Miller, W., Myers, E. W., \& Lipman, D. J. (1990). Basic local alignment search tool. Journal of Molecular Biology, 215(3), 403 - 410. DOI: https://doi.org/10.1016/S00222836(05)80360-2

Carvalho, C. M., Meirinho, S., Estevinho, M. L. F., \& Choupina, A. (2010). Yeast species associated with honey: Different identification methods. Archivos de zootecnia, 59(225), 103-113. Retrieved from https://www.uco.es/ucopress/az/index.php/az/article/view/4896/3142.

Cheng, C. K., Demirci, A., \& Catchmark, M. J. (2011). Pullulan: biosynthesis, production, and applications. Applied Microbiology and Biotechnology, 92(1), 29-44. DOI: https://doi.org/10.1007/s00253-011$3477-\mathrm{y}$

Delfini, C., \& Formica, J. V. (2001). Wine microbiology science and technology. Italy: CRC Press. Marcel Dekker Inc.

Deshpande, M. S., Rale, V. B., \& Lynch, J. M. (1992). Aureobasidium pullulans in applied microbiology: A status report. Enzyme and Microbial Technology, 14(7), 514-527. DOI: https://doi.org/10.1016/01410229(92)90122-5

Dodor, D. E., \& Tabatabai, M. A. (2007). Arylamidase activity as an index of nitrogen mineralization in soils.

Journal Communications in Soil Science and Plant Analysis, 38(15-16), 2197-2207. DOI: https://doi.org/10.1080/00103620701549132 
Duarte, W. F., Dragone, G., Dias, D. R., Oliveira, J, M., Teixeira, J. A., Almeida de Silva, J. B., \& Schwan, R. F. (2010). Fermentative behavior of Saccharomyces strains during micro vinification of raspberry juice (Rubus idaeus L.). International Journal of Food Microbiology, 143(3), 173-182. DOI: https://doi.org/10.1016/j.ijfoodmicro.2010.08.014

Esen, A. (2003). Hydrolases; $\beta$-Glucosidase. In J. R. Whitaker, A. G. J. Voragen, D. W. S. Wong (Eds.), Handbook of Food Enzymology (pp. 791-803), Dekker: New York.

Esteve-Zarzoso, B., Belloch, C., Uruburu, F., \& Querol, A. (1999). Identification of yeasts by RFLP analysis of the 5.8S rRNA gene and the two ribosomal internal transcribed spacers. International Journal of Systematic Bacteriology, 49(1), 329-337. DOI: https://doi.org/10.1099/00207713-49-1-329

Fleet, G. H., Charoenchai, C., Henschke, P. A., \& Todd, B. E. N. (1997). Screening of non-Saccharomyces wine yeasts for the presence of extracellular hydrolytic enzymes. Australian Journal of Grape and Wine Research, 3(1), 2-8. DOI: https://doi.org/10.1111/j.1755-0238.1997.tb00109.x

Garcia-Martos, P., Marin, P., Hernandez-Molina, J. M., Garcia-Agudo, L., Aoufi, S., \& Mira, J. (2001). Extracellular enzymatic activity in 11 Cryptococcus species. Mycopathologia, 150(1), 1-4. DOI: https://doi.org/10.1023/A:1010868223582

Gaur, R., Singh, R., Gupta, M. \&Gaur, M. K. (2015). Aureobasidium pullulans, an economically important polymorphic yeast with special reference to pullulan. African Journal of Biotechnology, 9(47), 79897997. DOI: https://doi.org/10.5897/AJB10.948

Gibson, B. R., Pham, T., Wimalasena, T., Box, W. G., Koivuranta, K., Storgards, E., \& Smart, K. A. (2011). Evaluation of ITS PCR and RFLP for differentiation and identification of brewing yeast and brewery 'wild' yeast contaminants. Journal of The Institute of Brewing, 117(4), 556-568. DOI: https://doi.org/10.1002/j.2050-0416.2011.tb00504.x

Göktaş, A. (2011). Ahududu ve bögürtlen yetişstiriciliği. Isparta Meyvecilik Araştırma İstasyonu Müdürlüğü, Yayın No: 38. Retrieved from: https://arastirma.tarimorman.gov.tr/marem

Guillamon, J. M., Sabate, J., Barrio, E., Cano, J., \& Querol, A. (1998). Rapid identification of wine yeast species based on RFLP analysis of the ribosomal internal transcribed spacer (ITS) region. Archives of Microbiology, 169(5), 387-392. DOI: https://doi.org/10.1007/s002030050587

Halvorsen, B. L. K., Holte, M. C. W., Myhrstad, I., Barikmo, E., Hvatttum, S. F., Remberg, A. B., Wold Haffner, H., Baugerod, L. F., Andersen, J., Moskaug, D. R., \& Blomhoff, J. R. (2001). A Systematic screening of total antioxidants in dietary plants. The Journal of Nutrition, 132(3), 461-471. DOI: https://doi.org/10.1093/jn/132.3.461

Hierro, N., Gonzalez, A., Mas, A., \& Guillamon, J. M. (2004). New PCR-based methods for yeast identification. Journal of Applied Microbiology, 97(4), 792-801. DOI: https://doi.org/10.1111/j.13652672.2004.02369.x

Johnson, E. A. (2013a). Biotechnology of non-Saccharomyces yeasts-the Ascomycetes. Applied Microbiology and Biotechnology, 97(2), 503-517. DOI: https://doi.org/10.1007/s00253-012-4497-y

Johnson, E. A. (2013b). Biotechnology of non-Saccharomyces yeasts - the Basidiomycetes. Applied Microbiology and Biotechnology, 97(17), 7563-7577. DOI: https://doi.org/10.1007/s00253-013-5046-Z

Johnson, E. A., \& Echavarri-Erasun, C. (2011). Yeast Biotechnology. In P.C. Kurtzman, J.W. Fell \& T. Boekhout (Eds.), The Yeasts, a Taxonomic Study, (pp. 22-44). Elsevier B.V.

Kallscheuer, N., Menezes, R., Foito, A., Da Silva, M. H., Braga, A., Dekker, W., Sevillano, D. M., RosadoRamos, R., Jardim, C., Oliveira, J., Ferreira, P., Rocha, I., Silva, A. R., Sousa, M., Allwood, J. W., 
Bott, M., Faria, N., Stewart, D., Ottens, M., Naesby, M., Dos Santos, C. N., \& Marienhagen, J. (2019). Identification and microbial production of the raspberry phenol salidroside that is active against Huntington's disease. Plant Physiology, 179(3), 969-985. DOI: https://doi.org/10.1104/pp.18.01074

Kähkönen, M. P., Hopia, A. I., Vuorela, H. J., Rauha, J. P., Pihlaja, K., Kujala, T. S., \& Heinonen, M. (1999). Antioxidant activity of plant extracts containing phenolic compounds. Journal of Agricultural and Food Chemistry, 47(10), 3954-3962. DOI: https://doi.org/10.1021/jf9901461

Krisch, J., Galgóczy, L., Papp, T., \& Vagvolgi, C. (2009). Antimicrobial and antioxidant potential of waste products remaining after juice pressing. Annals of the Faculty of Engineering Hunedoara-Journal of Engineering, 8(4), 131-134. Retrieved from: http://annals.fih.upt.ro/pdf-full/2009/ANNALS-2009-426.pdf

Kumar, S., Stecher, G., Li, M., Knyaz, C., \& Tamura, K. (2018). MEGA X: Molecular Evolutionary Genetics Analysis across computing platforms. Molecular Biology and Evolution, 35(6), 1547-1549. DOI: https://doi.org/10.1093/molbev/msy096

Lee, B. H. (1996). Fundamentals of Food Biotechnology, VCH Publishers, USA.

Leff, J. W., \& Fierer, N. (2013). Bacterial communities associated with the surfaces of fresh fruits and vegetables. PLoS ONE, 8(3), e59310. DOI: https://doi.org/10.1371/journal.pone.0059310

Liu, H. M., Guo, J., Cheng, Y. J., Liu, P., Long, C. A., \& Deng, B. X. (2010). Inhibitory activity of tea polyphenol and Hanseniaspora uvarum against Botrytis cinerea infections. Letters in Applied Microbiology, 51(3), 258-263. DOI: https://doi.org/10.1111/j.1472-765X.2010.02888.x

Lopez, V., Querol, A., Ramon, D., \& Fernandez-Espinar, M. T. (2001). A simplified procedure to analyze mitochondrial DNA from industrial yeasts. International Journal of Food Microbiology, 68(1-2), 7581. DOI: https://doi.org/10.1016/S0168-1605(01)00483-4

Masneuf-Pomarede, I., Bely, M., Marullo, P. \& Albertin, W. (2016). The genetics of non-conventional wine yeasts: current knowledge and future challenges. Frontiers in Microbiology, 6, 1563. DOI: https://doi.org/10.3389/fmicb.2015.01563

Nikolaou, E., Andrighetto, C., Lombardi, A., \& Nikolaos, T. (2007). Heterogeneity in genetic and phenotypic characteristics of Saccharomyces cerevisiae strains isolated from red and white wine fermentation. Food Control, 18(11), 1458-1465. DOI: https://doi.org/10.1016/j.foodcont.2006.11.004

Nikolaou, E., Soufleros, E. H., Boulompasi, E., \& Tzanetakis, N. (2006). Selection of indigenous Saccharomyces cerevisiae strains according to their oenological characteristics and vinification results. Food Microbiology, 23(3), 205-211. DOI: https://doi.org/10.1016/j.fm.2005.03.004

Peter, G., Tornai-Lehoczki, J., Suzuki, M., \& Dlauchy, D. (2005). Metschnikowia viticola sp. nov., a new yeast species from grape. Antony van Leeuwenhoek, 87(2), 155-160. DOI: https://doi.org/10.1007/s10482-004-2842-6

Puupponen-Pimia R., Nohynek, L., Hartmann-Schimidlin, S., Kahkonen, M., Heinonen, M., \& MaattaRiihinen, K. (2005). Berry phenolics selectively inhibit the growth of intestinal pathogens. Journal of Applied Microbiology, 98(4), 991-1000. DOI: https://doi.org/10.1111/j.1365-2672.2005.02547.x

Riaz, M., Ahmad, M., \& Rahman, N. (2011). Antimicrobial screening of fruit, leaves, root, and stem of Rubus fruticosus. Journal of Medicinal Plant Research, 24(5), 5920-5924. Retrieved from: https://academicjournals.org/article/article1381913021

Rodriguez-Vico, F, Clemente-Jimenez, J. M., Mingorance-Cazorla, L., Martinez-Rodriguez, S., \& Las Heras-Vazquez, F. J. (2003). Molecular characterization and oenological properties of wine yeasts isolat- 
ed during spontaneous fermentation of six varieties of grape must. Food Microbiology, 21(2), 149155. DOI: https://doi.org/10.1016/S0740-0020(03)00063-7

Romano, P., Capece, A, Siesto, G., \& Romaniello, R. (2009). Restriction analysis of rDNA regions to differentiate non-Saccharomyces wine species in mixed cultures. Journal of Engineering and Technology Research, 1(4), 068-071. Retrieved from: http://www.academicjournals.org/JETR

Sena, R. F., Costelli, M. C., Gibson, L. H., \& Coughlin, R. W. (2006). Enhanced production of pullulan by two strains of $A$. pullulans with different concentrations of soybean oil in sucrose solution in batch fermentations. Brazilian Journal of Chemical Engineering, 23(4), 507-515. DOI: https://doi.org/10.1590/S0104-66322006000400008

Sherman, F., Fink, G. R., \& Hicks, J. B. (1986). Methods in Yeast Genetics: A Laboratory Course Manual. Cold Spring Harbor, NY: Cold Spring Harbor Laboratory.

Spadaro, D., Vola, R., Piano, S., \& Gullino, M. L. (2002). Mechanisms of action and efficacy of four isolates of the yeast Metschnikowia pulcherrima active against postharvest pathogens on apples. Postharvest Biology and Technology, 24(2), 123-134. DOI: https://doi.org/10.1016/S0925-5214(01)00172-7

Sipiczki, M. (2020). Metschnikowia pulcherrima and Related Pulcherrimin-Producing Yeasts: Fuzzy Species Boundaries and Complex Antimicrobial Antagonism. Microorganisms, 8(1029), 1-19. DOI: https://doi.org/10.3390/microorganisms8071029

The Huntington's Disease Collaborative Research Group. (1993). A novel gene containing a trinucleotide repeat that is expanded and unstable on Huntington's disease chromosomes. Cell, 72(6), 971-83. DOI: https://doi.org/10.1016/0092-8674(93)90585-E

Tournas, V. H., Katsoudas, E. (2005). Mould and yeast flora in fresh berries, grapes and citrus juices. International Journal of Food Microbiology, 105(1), 11-17. DOI: https://doi.org/10.1016/j.ijfoodmicro.2005.05.002

Velićanski, A., Cvetković, D., \& Markov, S. (2012). Screening of antibacterial activity of raspberry (Rubus ideaus L.) fruit and pomace extracts. Acta Periodica Technologica, 43, 305-313. DOI: https://doi.org/10.2298/APT1243305V

Vero, S., Garmendia, G., Gonzalez, M. B., Garat, M. F., \& Wisniewski, M. (2009). Aureobasidium pullulans as a biocontrol agent of postharvest pathogens of apples in Uruguay. Biocontrol Science and Technology, 19(10), 1033-1049. DOI: https://doi.org/10.1080/09583150903277738

Wang, Q., Laamanen, J., Uosukainen, M., \& Valkonen Jari, P. T. (2005) Cryopreservation of In Vitro-grown shoot tips of raspberry (Rubus idaeus L.) by encapsulation-vitrification and encapsulationdehydration. Plant Cell Reports, 24(5), 280-288. DOI: https://doi.org/10.1007/s00299-005-0936-x

Wang, X., Li, S., Yang, X., Yang, S., \& Zhu, M. (2012). Technology prospecting on enzymes: application, marketing, and engineering. Computational and Structural Biotechnology Journal, 2(3), 1-11. DOI: https://doi.org/10.5936/csbj.201209017

Weber, C., \& Liu, R. H. (2002). Antioxidant capacity and anticancer properties of red raspberry. Acta Horticulturae, 585, 451-455. DOI: https://doi.org/10.17660/ActaHortic.2002.585.73

White, T. J., Bruns, T., Lee, S. \& Taylor, J. (1990). Amplification and direct sequencing of fungal ribosomal RNA genes for phylogenetics. In M. A. Innis, D. H. Gelfand, J. J. Sninsky \& T.J. White (Eds.), PCR Protocols: A Guide to Methods and Applications (pp. 315-322.), Academic Press, San Diego, California, USA. 